OPEN ACCESS

Edited by:

Kazuki Saito,

RIKEN Center for Sustainable Resource Science (CSRS), Japan

Reviewed by:

Vojislava Grbic

University of Western Ontario, Canada Lydia Fumiko Yamaguchi,

Universidade de São Paulo, Brazil

*Correspondence:

Renee M. Borges renee@iic.ac.in

Specialty section: This article was submitted to Plant Metabolism and Chemodiversity, a section of the journal Frontiers in Plant Science

Received: 05 March 2018 Accepted: 13 July 2018 Published: 07 August 2018

Citation: Borges RM (2018) The Galling Truth: Limited Knowledge of Gall-Associated Volatiles in Multitrophic Interactions. Front. Plant Sci. 9:1139. doi: 10.3389/fpls.2018.01139

\section{The Galling Truth: Limited} Knowledge of Gall-Associated Volatiles in Multitrophic Interactions

\author{
Renee M. Borges* \\ Centre for Ecological Sciences, Indian Institute of Science, Bengaluru, India
}

Galls are the product of enclosed internal herbivory where the gall maker induces a plant structure within which the herbivores complete their development. For successful sustained herbivory, gall makers must (1) suppress the induction of plant defenses in response to herbivory that is usually mediated through the jasmonic acid pathway and involves volatile organic compound (VOC) production, or (2) have mechanisms to cope with herbivory-induced VOCs, or (3) manipulate production of VOCs to their own advantage. Similarly, plants may have mechanisms (1) to avoid VOC suppression or (2) to attract galler enemies such as parasitoids. While research on VOCs involved in plant-herbivore-parasitoid/predator interactions is extensive, this has largely focussed on the impact of piercing, sucking, and chewing external herbivores or their eggs on VOC emissions. Despite the importance of gallers, owing to their damage to many economically valuable plants, the role of volatiles in gall-associated herbivory has been neglected; exceptions include studies on beneficial gallers and their enemies such as those that occur in brood-site pollination mutualisms. This is possibly the consequence of the difficulties inherent with studying internally occurring herbivory. This review examines the evidence for VOCs in galler attraction to host plants, potential VOC suppression by gallers, increased emission from galls and neighboring tissues, attraction of galler enemies, and the role of galler symbionts in VOC production. It suggests a research focus and ways in which studies on galler-associated VOCs can progress from a philatelic approach involving VOC listing toward a more predictive and evolutionary perspective.

Keywords: galler, herbivory, parasitoid, multitrophic interactions, plant-galler interactions, plant-insect interactions, volatile organic compounds, vOCs

\section{INTRODUCTION}

Galls are a classic example of niche construction (Gilbert, 2009) and partly of the extended phenotype of the galling organism (Stone and Cook, 1998). Galls are constructed by gallers in concert with plant tissue that is coerced into gall formation (Favery et al., 2016; Borges, 2017). These hypertrophied tissues provide protection and nutrition for one or more galler generations (Wool and Burstein, 1991). Diverse organisms including viruses, bacteria, fungi, and invertebrates induce galls on plants (Mani, 1964; Raman, 2011; Fernandes and Santos, 2014). Of invertebrates, galling insects are possibly the most diverse and most studied and include gall midges (Diptera: Cecidomyiidae), gall wasps (Hymenoptera: Cynipidae), and aphids (Hemiptera: 
Aphididae); nematodes and mites are also important. Most galls are an infestation; to be sustained, gallers must suppress or cope with plant defenses such as herbivore-induced plant volatiles (HIPVs) or manipulate them to their own advantage (Figure 1). This review is restricted to invertebrate-induced galls, and focuses on the less-examined role of volatiles in galler-plantgaller enemy interactions (Figure 1). Beneficial galls occur in some brood-site pollination mutualisms when gallers themselves are pollinators, e.g., fig wasps (Borges, 2016; Figure 2). Here the interests of the host-plant and the gallers are aligned, and plants actively signal to their galler pollinators.

\section{PLANT VOLATILE ORGANIC COMPOUNDS (VOCS) THAT ATTRACT GALLERS}

Plant tissues rich in meristems are likely most suitable for gall initiation (Carneiro et al., 2017; Silvia and Connor, 2017) and should attract gallers.

\section{Floral Volatiles}

In the fig pollination mutualism, where gallers are pollinators and gall individual flowers at the expense of seeds, a diverse volatile organic compound (VOC) blend attracts agaonid wasp pollinators (Hossaert-McKey et al., 2010; Borges, 2016). These are likely produced by glandular cells in the outer wall of fig syconia (enclosed globular inflorescences) or in bracts surrounding the syconium opening at the pollen-receptive stage (Souza et al., 2015). These blends comprise mostly terpenoids, with some benzenoids and aliphatic compounds (Borges, 2016). In one study, 4-methylanisole was proposed as the major pollinator attractant (Chen et al., 2009). Another study determined that enantiomeric mixtures of some dominant monoterpenes were more attractive to pollinators than others (Chen and Song, 2008). Besides pollinating gallers, most fig syconia also harbor non-pollinating, parasitic galler wasp species (Herre et al., 2008); these arrive for oviposition either very early or much later in the development of the syconium (Segar et al., 2013) attracted by stage-specific VOCs; some species are attracted to the same blends that attract pollinating gallers (Borges et al., 2013; Figure 2C), and therefore exploit signals meant for mutualistic gallers.

Sometimes floral VOCs serves as cues for leaf gallers. Floral volatiles in Salix are long-distance attractants for leaf-galling sawflies Pontania proxima (Kehl et al., 2010). Although the target galling sites are leaves, flowering twigs produce 90 times more VOC quantities than non-flowering twigs suggesting that using floral volatiles as a proxy for leaves may be an efficient hostfinding strategy; more flowering than non-flowering plants were galled. In electroantennogram detection (EAD) studies on VOCs from male flowering twigs, compounds absent from vegetative VOC blends, e.g., 1,4-dimethoxybenzene, were strongly detected by sawfly antennae, confirming that such floral compounds may constitute key attractants for leaf gallers. Interestingly, the antennae also responded to green leaf volatiles (GLVs).

\section{Stem and Leaf Volatiles}

Considering the voluminous research on cecidomyiid and cynipid galls, very little work exists on host volatiles as attractants. Volatiles of flowering stems of the herbaceous perennial Silphium (Asteraceae) attracted the cynipid gall wasp Antistrophus rufus (Tooker et al., 2005). A monoterpene blend consisting of a racemic mixture of $\alpha$-pinene and $\beta$-pinene ( + for both), $(+)$ limonene, and $(-)$ camphene served as principal attractants for ovipositing females (Tooker et al., 2005). The compound ratios in the blend must be crucial since these monoterpenes are present in sympatric Silphium species to which the cynipids are not attracted. Male cynipid wasps use parts of this same blend to locate females within galled stems indicating that host volatiles are employed as mate location cues (Tooker et al., 2002; Tooker and Hanks, 2004) as in several other non-galling phytophagous insects (Xu and Turlings, 2018). The cynipid chestnut gall wasp Dryocosmus kuriphilus was attracted to a GLV blend from Castanea stems 60-120 min after damage, and failed to be attracted to intact stems (Germinara et al., 2011). All these compounds were detected by wasp antennae. C6 volatiles from young apple leaves were major attractants, eliciting EAD responses in the apple cecidomyiid midge Dasineura mali (Anfora et al., 2005). Female orange wheat blossom cecidomyiid midges Sitodiplosis mosellana were attracted by key compounds, e.g., (Z)-3-hexenyl acetate, acetophenone, and 3-carene, present in minor proportions in the overall volatile profile of wheat panicles (Birkett et al., 2004). The African rice gall cecidomyiid midge Orseolia oryzivora preferred volatiles from uninfested plants while those from infested plants served as repellents; the major difference between these volatile profiles was a considerable increase in the HIPV (E)- $\beta$-caryophyllene (Ogah et al., 2017).

\section{Root Volatiles}

For root-knot nematodes, $\mathrm{CO}_{2}$ seems to be the most important attractant released by actively respiring roots (Rasmann et al., 2012); there is scant information on other root volatiles that serve as galler/plant parasitic nematode attractants in the absence of plant damage (Rasmann et al., 2012; Johnson and Rasmann, 2015). Low concentrations of lauric or dodecanoic acid attract root-knot nematodes while this VOC is repellent at high levels (Dong et al., 2014).

\section{IMPACT OF GALL MAKERS ON PLANT VOLATILES}

\section{Suppression of Volatile Production}

A successful galling strategy may require that gall makers suppress the induction of plant defenses (Kant et al., 2015), since a galler must have prolonged residence within the plant. Since many plant-induced defenses involve activation of the jasmonic acid (JA) pathway, which also often results in volatile release, it is therefore not surprising that VOC production is often suppressed during galling. A meta-analysis of secondary metabolites that are up-regulated on gall induction found that, unlike other 


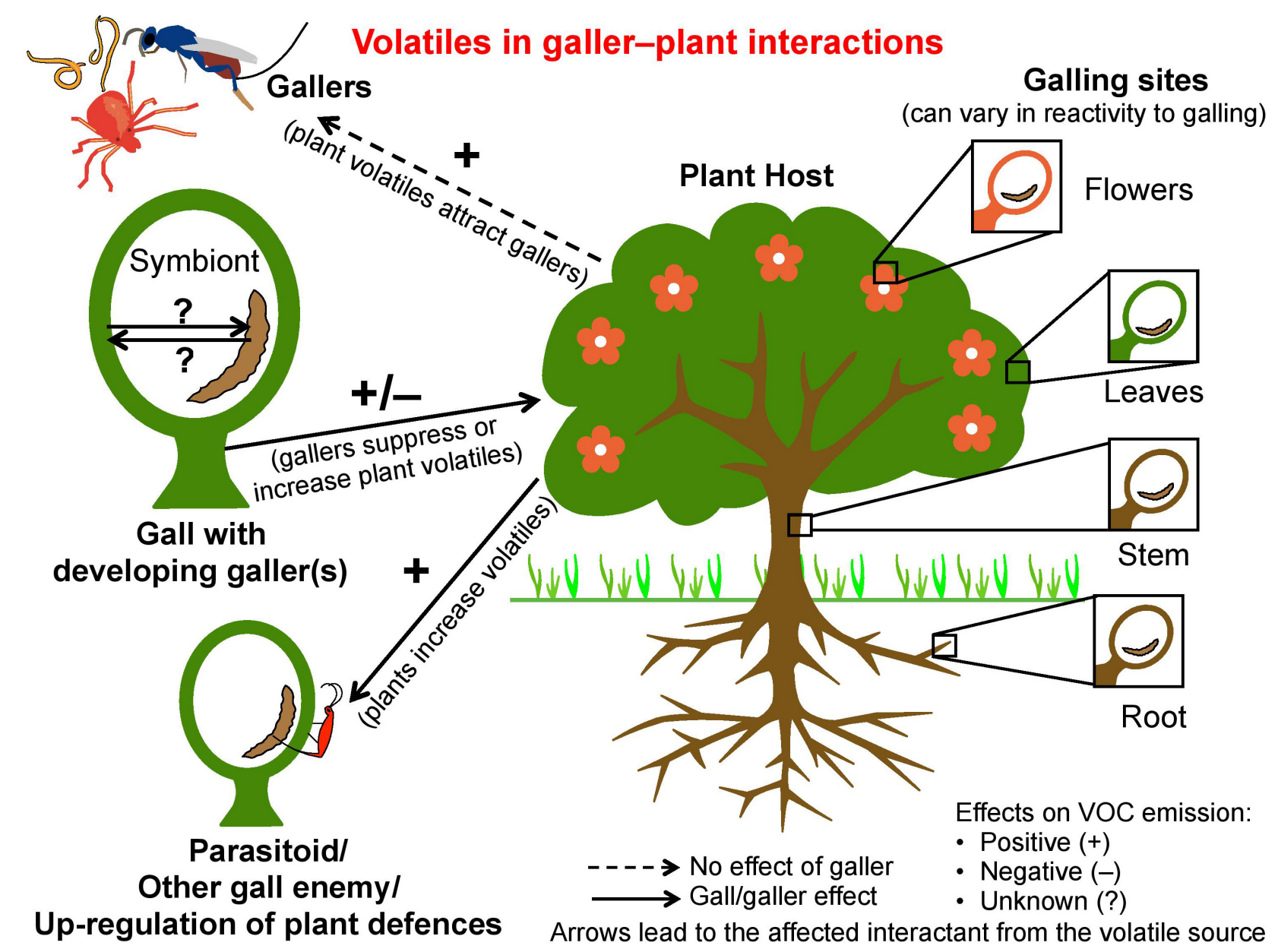

FIGURE 1 | Interactions between gallers and plants by means of volatiles. Arrows point toward the affected interactant from the volatile source. Volatiles may attract gallers to plants; the galler may suppress plant volatile production, or plants may increase volatile production to attract galler enemies or to up-regulate defenses. Symbionts within galls or gallers may affect volatile production.

metabolites, volatiles were usually unaffected (Hall et al., 2017). For example, goldenrod plants Solidago altissima showed no increase in VOC emission after attack by galling flies Eurosta solidagnis or galling moths Gnorimoschema gallaesolidaginis (Tooker et al., 2008), as also in Japanese elms attacked by galling aphids (Takei et al., 2015). Furthermore, infestation by E. solidagnis suppressed HIPVs in response to subsequent herbivory by generalist caterpillars (Tooker et al., 2008). Consistent with JA suppression, galls accumulated salicylic acid (SA) instead (Tooker et al., 2008). Tooker and De Moraes (2008) speculate that gallers are adapted to suppress JA, since JA inhibits plant growth hormones such as auxin and also cytokinins, both of which must be locally up-regulated in gall formation (Tooker and Helms, 2014). Whether gallers can suppress ethylene production which could impact VOC production (Broekgaarden et al., 2015) is unknown. Some insect gallers may synthesize phytohormones, e.g., auxin (Bailey et al., 2015); this may impact JA synthesis as suggested by cross-talk between auxin and JA observed in many plant-associated bacteria and fungi (Berens et al., 2017). Gallers may succeed in suppressing plant defenses by deploying effector molecules (Zhao et al., 2015) among which are ATPhydrolysing enzymes, calcium-binding proteins, and ubiquitin ligases (Giron et al., 2016; Guiguet et al., 2016; Nabity, 2016).

Five non-mutually exclusive mechanisms have been suggested for the absence of increased VOC emission after galling (Tooker et al., 2008). Besides the SA up-regulation mentioned above, they include (a) avoidance of galler detection, (b) targetting relatively non-reactive tissues, e.g., stems, (c) depletion by galler larvae of plant resources needed for VOC production, and (d) active suppression of host-plant defense (e.g., Nyman and JulkunenTiitto, 2000).

\section{Increase in Volatiles After Galling}

While gallers often suppress VOCs, increased VOC production in and around galled tissues may occur. In flower galls produced by the dipteran Myopites stylatus on the woody fleabane Dittrichia viscosa (Asteraceae), emission of the phenylpropene compound estragole, an isomer of anethole, increased six times compared to ungalled flowers (Santos et al., 2016). A moderate increase in anethole was also evident. The terpene eucalyptol (1,8-cineole) 
A

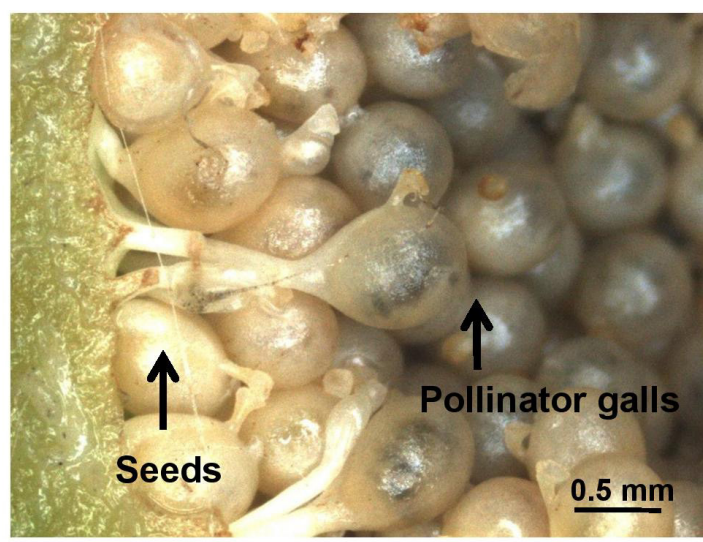

C

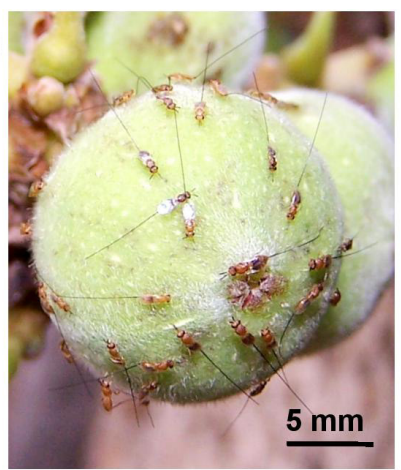

D
B
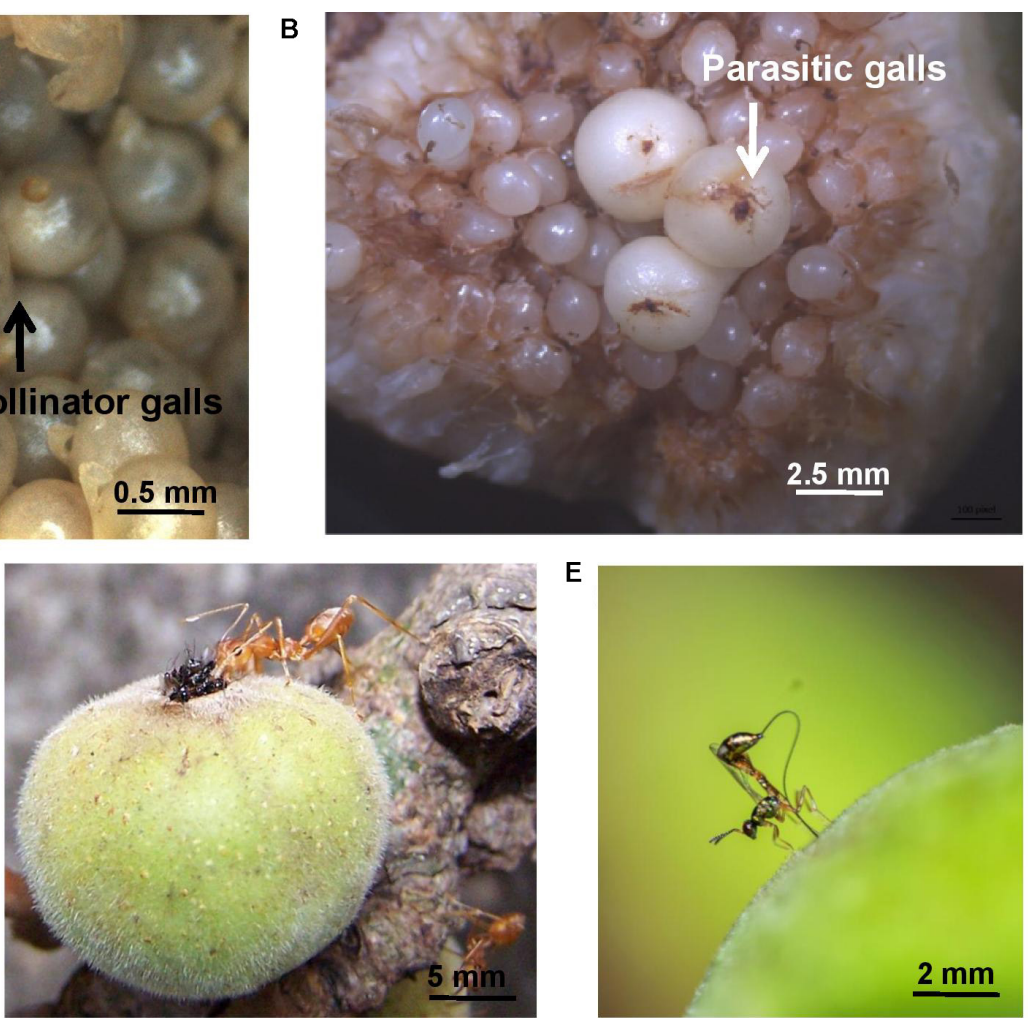

E

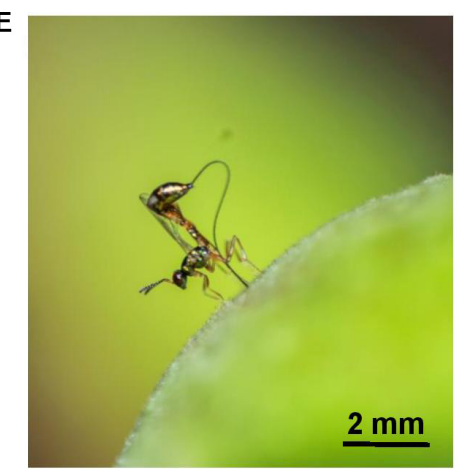

FIGURE 2 | Interactions of plants with beneficial and parasitic gallers. Examples are from the cluster fig Ficus racemosa (A) seeds and pollinator galls in a syconium. Note remnants of stigma and single developing pollinator in each galled uniovulate flower. (B) Large galls of an early-arriving parasitic galler Sycophaga stratheni in a syconium; these gallers target tissues of the syconium lumen. (C) Aggregations of parasitic gallers Sycophaga fusca on a syconium; these gallers are attracted by the syconium volatile blend emitted at pollen-receptive stage. (D) The weaver ant Oecophylla smaragdina preying upon pollinator gallers Ceratosolen fusciceps entering a syconium through the ostiole; ants are attracted by syconial volatiles at pollen-receptive phase. (E) Oviposition by parasitoid Apocrypta sp. 2 into galls hidden within the syconium; oviposition decision are made using chemosensory features of the ovipositor. Photo credits: (A,D) Mahua Ghara and Yuvaraj Ranganathan; (B,C) Pratibha Yadav; image in C is adapted from Yadav et al. (2018) and is reproduced with permission from Springer Nature; (E) Nikhil More.

was emitted in large quantities only from galls, and was absent from floral scents. However, the gall emission of compounds such as $\alpha$-pinene, $\beta$-pinene, limonene, and linalool was significantly lowered. Terpenes such as $\alpha$-pinene, limonene, and linalool may have a toxic but hormetic effect on dipterans (Papanastasiou et al., 2017), while estragole and anethole are generally toxic to dipterans (Chang et al., 2009). Eucalyptol emitted by another Asteraceae plant was a repellent and oviposition-deterrent to mosquitoes (Klocke et al., 1987). Many interesting questions arise from these observations on the fleabane-fly interaction. First, the concentrations of the VOCs within the gall are unknown; therefore, whether high concentrations of estragole and anethole are also present within gall tissues is not known. If the gall also contains high amounts of these phenylpropanoids, that are usually toxic to many insects, one may speculate that the galler larvae/pupae are resistant to these toxins. If so, are they being produced by the galler by hijacking plant biochemical machinery to their advantage, so that non-resistant galler enemies such as parasitoids are also deterred? Additionally, is it possible that concentrations of $\alpha$-pinene, limonene, and linalool are lowered within the gall to non-toxic but hormetic levels under the action of the galler? Is eucalyptol being produced in very high quantities to deter galler enemies such as parasitoids or for its antifungal/antibacterial activities? The parasitoids of this tephritid fly species include eurytomid, eupelmid, pteromalid and torymid wasps, and appear to be attracted by gall and/or host cues (Santos et al., 2016). It is also possible that gallers are unable to manipulate VOC release and that VOC emission is under multifactorial control resulting in unexpected VOC emission patterns.

In another example, the aphid Baizongia pistaciae induces galls on the terminal buds of the pistachio Pistacia palaestina (Anacardiaceae). Gall tissue extracts contained much higher levels of terpenes, especially $\alpha$-pinene and limonene, than surrounding ungalled leaves, while leaves accumulated more sesquiterpenes (Rand et al., 2014). The high terpene levels resulted from increased biosynthetic activity within the galls rather than accumulation from surrounding tissue (Rand et al., 2017). High terpene levels within the gall could result from a need for antibacterial/antifungal activity, or to deter parasitoids. Stored and emitted terpenes were also in higher concentrations in galls formed by the aphid Slavum wertheimae on the lateral buds of Pistacia atlantica (Rostás et al., 2013). Concentrations of three terpenes, i.e., $\alpha$-pinene, limonene, and sabinene, were 
much higher compared to others. The principal galler enemies in this study were mammalian herbivores, i.e., goats, that were reluctant to consume galls or food pellets to which these three terpenes were added in biologically relevant concentrations. While the authors speculate that terpenes were largely responsible for the feeding deterrence, they admit that the high gall tannin concentrations may also have deterrent effects.

In the oak Quercus robur, cynipid galls do not have altered VOC emissions but affect emissions of neighboring portions of gall-bearing leaves (Jiang et al., 2018). The change in leaf emission depends on whether the galler attacks major veins or intercostal areas. Major vein galls resulted in more GLV production and less terpenes from neighboring tissues, while galls in undifferentiated parenchyma of intercostal areas resulted in much more terpene and benzenoid production. Notably both types of galls caused increased $\alpha$-pinene and limonene emission, while the intercostal tissue galls also induced the emission of other monoterpenes such as linalool, camphene, $\beta$-myrcene, and the sesquiterpene $\beta$-bergamotene that were not produced by ungalled leaves. Galls also produced far less isoprene than ungalled leaves. Therefore, in this example also, monoterpene production was most affected. Similarly, an increase in $\alpha$-pinene and limonene emission occurred in galls induced by psyllids on Schinus polygamus (Anacardiaceae) (Damasceno et al., 2010); C6 volatiles increased in neighboring leaf portions bearing the galls.

In S. altissima attacked by the rosette gall-midge Rhopalomyia solidaginis, emissions of terpenes such as copaene and $\beta$-pinene increased post-galling (Uesugi et al., 2016); these attracted herbivorous beetles whose presence facilitated galler performance, suggesting that VOC emission patterns must be viewed in an integrated manner.

\section{PLANT OR GALL VOLATILES THAT ATTRACT GALLER ENEMIES}

Herbivore-induced plant volatiles used by parasitoids in host location have been largely investigated for externally feeding chewing, piercing, and sucking herbivores (Aartsma et al., 2017), where herbivore feeding mode appears an accurate predictor of the HIPV blend (Danner et al., 2017). Surprisingly, there is almost no work on VOCs attracting parasitoids to galls. While Borges et al. (2013) examined changes in the volatilome during fig syconial development, including stages when a multiplicity of gallers and parasitoids of these gallers are also attracted, here too, the study did not specifically test a set of volatiles on parasitoids. Using an adaptation of weighted gene coexpression network analysis (WGCNA), co-emitted modules of VOCs were detected. Early-arriving gallers triggered the release of GLVs such as $(Z)$-3-hexenyl acetate and $(Z)$-3-hexenol. Later-arriving gallers triggered the release of compounds such as $(E)$ - $\beta$-ocimene, $(Z)$ $\beta$-ocimene, and methyl salicylate in response to galler feeding; these are well known HIPVs and parasitoid attractants in other plant-herbivore systems (Turlings and Erb, 2018). In Y-tube olfactometer experiments, parasitoid wasps were attracted by VOCs of fig syconia containing their galler hosts (Proffit et al., 2007). Such attracted parasitoids make decisions about which galls to parasitise by sampling syconial odors with their probing ovipositor. For the first time, Yadav and Borges (2017) showed that the ovipositor of fig wasp gallers and parasitoids is a volatile sensor, and that it responds both behaviourally as well as with neuronal firing to cues such as $\mathrm{CO}_{2}$ and syconial stage-specific volatiles. For parasitoids that need to seek out hidden hosts within galls (Figure 2E), the use of cues such as $\mathrm{CO}_{2}$ that signal locations of actively respiring galler larvae/pupae are potentially extremely important in successful parasitism. Parasitoids in the fig system may be considered apparent mutualists if they target non-beneficial gallers or control the population of pollinating gallers within fig syconia (Krishnan et al., 2015); therefore, the role of VOCs in maintaining such tritrophic interactions in order to stabilize the core mutualism is likely profound.

Volatiles emitted by fig syconia in pollen-receptive phase to attract galling pollinators are also attractive to predatory ants that eavesdrop on this pollinator signal (Ranganathan and Borges, 2009; Figure 2D). These ants are also attracted to syconial volatiles at a later stage when F1 galler wasps and parasitoids exit the syconia; ant attraction toward stage-specific volatiles in Y-tube olfactometer tests is a learnt association based on prior exposure to syconial volatiles (Ranganathan and Borges, 2009). Since ants are important predators of galler and parasitoid fig wasps (Ranganathan et al., 2010; Bain et al., 2014), and are also important in other galling systems (Fernandes et al., 1999), their response to gall-associated volatiles deserves more attention.

Inquilines of gallers are also attracted by volatiles. Goldenrod Solidago stems are infested by galls induced by E. solidaginis tephritid flies. These flies can infest S. altissima and Solidago gigantea plants, and in turn their galls are attacked by gallboring inquiline beetles Mordellistena convicta. These beetles were attracted to volatiles associated with galls of their natal host plants, and avoided those of alternate host plants occupied by their galler hosts suggesting that inquiline speciation and subsequent radiation is driven by olfaction (Rhodes et al., 2012). The inquiline wasps Diaziella yangi and Lipothymus sp. that parasitise the pollinating galler Eupristina sp. of Ficus curtipes are attracted by 6-methyl-5-hepten-2-one (Gu and Yang, 2013) which is an important volatile in the pollen-receptive scent of the fig syconium (Gu et al., 2012); they showed no attraction to 6-methyl-5-hepten-2-ol which is another important scent constituent.

\section{ROLE OF SYMBIONTS IN GALLER-PLANT INTERACTIONS}

Plant scents may be influenced by symbionts. For example, bacteria have been recently implicated in VOC production in floral tissues (Helletsgruber et al., 2017). Bacteria in oral secretions of caterpillars can also suppress JA responses (Wang et al., 2016). Fungal root symbionts can influence aboveground production of HIPVs that attract parasitoids (Rasmann et al., 2017; Simon et al., 2017). Whether microbes are involved in VOC production that is beneficial to the galler or to the plant is as yet unknown (Figure 1). However, symbiosis has benefitted many 
gall-inducing insect lineages such as ambrosia gall midges whose diversification has been aided by fungal symbionts (Joy, 2013). The role of endophytic fungi present in many insect-induced galls is also unknown (Lawson et al., 2014).

\section{CONCLUSION}

\section{Moving From Philately to Understanding the Volatilome}

While information is still scarce, gall induction may affect the volatilome of plants. Making sense of this effect may be tackled at several levels. (1) Classes of VOCs may have particular relevance at different stages of galler-plant interactions. For example, that many gallers are attracted to non-specific GLVs suggests that GLVs are used as habitat cues rather than hostspecific cues (Webster and Cardé, 2017) and enable navigation toward suitable vegetation patches from long distances. (2) Mirroring research on externally feeding herbivores, where HIPVs have been investigated from the egg-laying stage (Hilker and Fatouros, 2015), comparable information is needed in gallerplant-parasitoid/inquiline interactions including stages such as tissue damage by ovipositor probing, egg laying, damage by larval mandibles, and finally gall induction. (3) Metabolic plasticity can occur in host-plant-galler interactions vis-a-vis different gallers and plant genotypes (Uesugi et al., 2013, 2016), resulting in varied responses that must, therefore, be interpreted within the context of the specific interactants. (4) We need to understand correlation networks of VOCs produced by plants under a variety of circumstances. Junker et al. (2017) and Junker (2017) have examined enzymatic and volatile hubs; such efforts may lead to predictions and an understanding of why certain VOCs tend to co-occur, e.g., $\alpha$-pinene, limonene, and linalool in many of the above-cited examples. (5) Chemists and behavioral ecologists

\section{REFERENCES}

Aartsma, Y., Bianchi, F. J., Werf, W., Poelman, E. H., and Dicke, M. (2017) Herbivore-induced plant volatiles and tritrophic interactions across spatial scales. New Phytol. 216, 1054-1063. doi: 10.1111/nph.14475

Adebesin, F., Widhalm, J. R., Boachon, B., Lefèvre, F., Pierman, B., Lynch, J. H., et al. (2017). Emission of volatile organic compounds from petunia flowers is facilitated by an ABC transporter. Science 356, 1386-1388. doi: 10.1126/science. aan 0826

Anfora, G., Ioriatti, C., Moser, S., Germinara, G. S., and de Cristofaro, A. (2005). Electrophysiological responses of two species of apple gall midges (Diptera: Cecidomyiidae) to host plant volatiles. IOBC/WPRS Bull. 28, 413-417.

Bailey, S., Percy, D. M., Hefer, C. A., and Cronk, Q. C. (2015). The transcriptional landscape of insect galls: psyllid (Hemiptera) gall formation in Hawaiian Metrosideros polymorpha (Myrtaceae). BMC Genomics 16:943. doi: 10.1186/ s12864-015-2109-9

Bain, A., Harrison, R. D., and Schatz, B. (2014). How to be an ant on figs. Acta Oecol. 57, 97-108. doi: 10.1016/j.actao.2013.05.006

Berens, M. L., Berry, H. M., Mine, A., Argueso, C. T., and Tsuda, K. (2017). Evolution of hormone signaling networks in plant defense. Annu. Rev. Phytopathol. 55, 401-425. doi: 10.1146/annurev-phyto-080516-035544

Birkett, M. A., Bruce, T. J., Martin, J. L., Smart, L. E., Oakley, J. O. N., and Wadhams, L. J. (2004). Responses of female orange wheat blossom midge, Sitodiplosis mosellana, to wheat panicle volatiles. J. Chem. Ecol. 30, 1319-1328. doi: 10.1023/B:JOEC.0000037742.05022.9f must appreciate the importance of VOCs produced in small quantities; small peaks are often ignored at analytical and testing stages, but these may often contain the real signaling messages (Clavijo McCormick et al., 2014). (6) Since VOC emission is likely an active process controlled by transporters across plant cell membranes (Adebesin et al., 2017), and is not merely controlled by physical processes such as volatility (Borges et al., 2013), the field of plant signaling using volatiles must move toward making predictions about the costs and benefits of VOC production, types of VOCs expected, and their consequences. Only then will the study of volatiles progress from philately to viewing gall-associated volatiles within an ecological and evolutionary framework.

\section{AUTHOR CONTRIBUTIONS}

The author confirms being the sole contributor of this work and approved it for publication.

\section{FUNDING}

Work in my laboratory has been generously supported by the Department of Science and Technology (DST), DSTFIST, Department of Biotechnology, Council of Scientific and Industrial Research (CSIR), and Ministry of Environment, Forest \& Climate Change (MoEF\&CC).

\section{ACKNOWLEDGMENTS}

I am extremely grateful to Nikita Zachariah and Pratibha Yadav for assistance with Figures 1 and 2, respectively.

Borges, R. M. (2016). "On the air: broadcasting and reception of volatile messages in brood-site pollination mutualisms," in Deciphering Chemical Language of Plant Communication, eds J. D. Blande and R. Glinwood (Berlin: Springer International Publishing), 227-255.

Borges, R. M. (2017). Co-niche construction between hosts and symbionts: ideas and evidence. J. Genet. 96, 483-489. doi: 10.1007/s12041-017-0792-9

Borges, R. M., Bessière, J.-M., and Ranganathan, Y. (2013). Diel variation in fig volatiles across syconium development: making sense of scents. J. Chem. Ecol. 39, 630-642. doi: 10.1007/s10886-013-0280-5

Broekgaarden, C., Caarls, L., Vos, I. A., Pieterse, C. M., and Van Wees, S. C. (2015). Ethylene: traffic controller on hormonal crossroads to defense. Plant Physiol. 169, 2371-2379. doi: 10.1104/pp.15.01020

Carneiro, R. G., Isaias, R., Moreira, A. S., and Oliveira, D. C. (2017). Reacquisition of new meristematic sites determines the development of a new organ, the Cecidomyiidae gall on Copaifera langsdorffii Desf. (Fabaceae). Front. Plant Sci. 8:1622. doi: 10.3389/fpls.2017.01622

Chang, C. L., Cho, I. K., and Li, Q. X. (2009). Insecticidal activity of basil oil, trans-anethole, estragole, and linalool to adult fruit flies of Ceratitis capitata, Bactrocera dorsalis, and Bactrocera cucurbitae. J. Econ. Entomol. 102, 203-209. doi: 10.1603/029.102.0129

Chen, C., and Song, Q. (2008). Responses of the pollinating wasp Ceratosolen solmsi marchali to odor variation between two floral stages of Ficus hispida. J. Chem. Ecol. 34, 1536-1544. doi: 10.1007/s10886-008-9558-4

Chen, C., Song, Q., Proffit, M., Bessière, J.-M., Li, Z., and Hossaert-McKey, M. (2009). Private channel: a single unusual compound assures specific pollinator 
attraction in Ficus semicordata. Funct. Ecol. 23, 941-950. doi: 10.1111/j.13652435.2009.01622.x

Clavijo McCormick, A., Gershenzon, J., and Unsicker, S. B. (2014). Little peaks with big effects: establishing the role of minor plant volatiles in plant-insect interactions. Plant Cell Environ. 37, 1836-1844. doi: 10.1111/pce.12357

Damasceno, F. C., Nicolli, K. P., Caramão, E. B., Soares, G. L., and Zini, C. A. (2010). Changes in the volatile organic profile of Schinus polygamus (Anacardiaceae) and Baccharis spicata (Asteraceae) induced by galling psyllids. J. Braz. Chem. Soc. 21, 556-563. doi: 10.1590/S0103-50532010000300023

Danner, H., Desurmont, G. A., Cristescu, S. M., and van Dam, N. M. (2017). Herbivore-induced plant volatiles accurately predict history of coexistence, diet breadth, and feeding mode of herbivores. New Phytol. doi: 10.1111/nph.14428 [Epub ahead of print].

Dong, L., Li, X., Huang, L., Gao, Y., Zhong, L., Zheng, Y., et al. (2014). Lauric acid in crown daisy root exudate potently regulates root-knot nematode chemotaxis and disrupts Mi-flp-18 expression to block infection. J. Exp. Bot. 65, 131-141.

Favery, B., Quentin, M., Jaubert-Possamai, S., and Abad, P. (2016). Gall-forming root-knot nematodes hijack key plant cellular functions to induce multinucleate and hypertrophied feeding cells. J. Insect Physiol. 84, 60-69. doi: 10.1016/j. jinsphys.2015.07.013

Fernandes, G. W., Fagundes, M., Woodman, R. L., and Price, P. W. (1999). Ant effects on three-trophic level interactions: plant, galls, and parasitoids. Ecol. Entomol. 24, 411-415. doi: 10.1046/j.1365-2311.1999.00218.x

Fernandes, G. W., and Santos, J. C. (eds). (2014). Neotropical Insect Galls. Dordrecht: Springer. doi: 10.1007/978-94-017-8783-3

Germinara, G. S., De Cristofaro, A., and Rotundo, G. (2011). Chemical cues for host location by the chestnut gall wasp, Dryocosmus kuriphilus. J. Chem. Ecol. 37, 49-56. doi: 10.1007/s10886-010-9893-0

Gilbert, S. F. (2009). "The adequacy of model systems for evo-devo: modeling the formation of organisms/modeling the formation of society," in Mapping the Future of Biology. Evolving Concepts and Theories, Boston Studies in the Philosophy of Science, eds A. Barberousse, M. Morange, and T. Pradeu (Dordrecht: Springer), 57-68.

Giron, D., Huguet, E., Stone, G. N., and Body, M. (2016). Insect-induced effects on plants and possible effectors used by galling and leaf-mining insects to manipulate their host-plant. J. Insect Physiol. 84, 70-89. doi: 10.1016/j.jinsphys. 2015.12.009

Gu, D., Compton, S. G., Peng, Y., and Yang, D. (2012). 'Push' and 'pull' responses by fig wasps to volatiles released by their host figs. Chemoecology 22, 217-227. doi: 10.1007/s00049-012-0108-8

Gu, D., and Yang, D. R. (2013). Utilisation of chemical signals by inquiline wasps in entering their host figs. J. Insect Physiol. 59, 1065-1068. doi: 10.1016/j.jinsphys. 2013.08.005

Guiguet, A., Dubreuil, G., Harris, M. O., Appel, H. M., Schultz, J. C., Pereira, M. H., et al. (2016). Shared weapons of blood-and plant-feeding insects: surprising commonalities for manipulating hosts. J. Insect Physiol. 84, 4-21. doi: 10.1016/ j.jinsphys.2015.12.006

Hall, C. R., Carroll, A. R., and Kitching, R. L. (2017). A meta-analysis of the effects of galling insects on host plant secondary metabolites. Arthropod Plant Interact. 11, 463-473. doi: 10.1007/s11829-016-9486-0

Helletsgruber, C., Dötterl, S., Ruprecht, U., and Junker, R. R. (2017). Epiphytic bacteria alter floral scent emissions. J. Chem. Ecol. 43, 1073-1077. doi: 10.1007/ s10886-017-0898-9

Herre, E. A., Jandér, K. C., and Machado, C. A. (2008). Evolutionary ecology of figs and their associates: recent progress and outstanding puzzles. Annu. Rev. Ecol. Evol. Syst. 39, 439-458. doi: 10.1146/annurev.ecolsys.37.091305.110232

Hilker, M., and Fatouros, N. E. (2015). Plant responses to insect egg deposition. Annu. Rev. Entomol. 60, 493-515. doi: 10.1146/annurev-ento-010814-020620

Hossaert-McKey, M., Soler, C., Schatz, B., and Proffit, M. (2010). Floral scents: their roles in nursery pollination mutualisms. Chemoecology 20, 75-88. doi: $10.1093 / \mathrm{aob} / \mathrm{mcx} 024$

Jiang, Y., Veromann-Jürgenson, L. L., Ye, J., and Niinemets, Ü (2018). Oak gall wasp infections of Quercus robur leaves lead to profound modifications in foliage photosynthetic and volatile emission characteristics. Plant Cell Environ. 41, 160-175. doi: $10.1111 /$ pce. 13050

Johnson, S. N., and Rasmann, S. (2015). Root-feeding insects and their interactions with organisms in the rhizosphere. Annu. Rev. Entomol. 60, 517-535. doi: 10.1146/annurev-ento-010814-020608
Joy, J. B. (2013). Symbiosis catalyses niche expansion and diversification. Proc. $R$. Soc. Lond. B 280:20122820. doi: 10.1098/rspb.2012.2820

Junker, R. R. (2017). A biosynthetically informed distance measure to compare secondary metabolite profiles. Chemoecology 28, 29-37. doi: 10.1007/s00049017-0250-4

Junker, R. R., Kuppler, J., Amo, L., Blande, J. D., Borges, R. M., van Dam, N. M., et al. (2017). Covariation and phenotypic integration in chemical communication displays: biosynthetic constraints and eco-evolutionary implications. New Phytol. doi: 10.1111/nph.14505 [Epub ahead of print].

Kant, M. R., Jonckheere, W., Knegt, B., Lemos, F., Liu, J., Schimmel, B. C. J., et al. (2015). Mechanisms and ecological consequences of plant defence induction and suppression in herbivore communities. Ann. Bot. 115, 1015-1051. doi: $10.1093 / \mathrm{aob} / \mathrm{mcv} 054$

Kehl, A., Dötterl, S., Aas, G., and Rambold, G. (2010). Is flower scent influencing host plant selection of leaf-galling sawflies (Hymenoptera, Tenthredinidae) on willows? Chemoecology 20, 215-221. doi: 10.1007/s00049-0100050-6

Klocke, J. A., Darlington, M. V., and Balandrin, M. F. (1987). 1, 8-cineole (eucalyptol), a mosquito feeding and ovipositional repellent from volatile oil of Hemizonia fitchii (Asteraceae). J. Chem. Ecol. 13, 2131-2141. doi: 10.1007/ BF01012562

Krishnan, A., Ghara, M., Kasinathan, S., Pramanik, G. K., Revadi, S., and Borges, R. M. (2015). Plant reproductive traits mediate tritrophic feedback effects within an obligate brood-site pollination mutualism. Oecologia 179, 797-809. doi: 10.1007/s00442-015-3372-9

Lawson, S. P., Christian, N., and Abbot, P. (2014). Comparative analysis of the biodiversity of fungal endophytes in insect-induced galls and surrounding foliar tissue. Fungal Divers. 66, 89-97. doi: 10.1007/s13225-013-0268-z

Mani, M. S. (1964). The Ecology of Plant Galls. Monographiae Biologicae, Vol. 12. The Hague: W. Junk. doi: 10.1007/978-94-017-6230-4

Nabity, P. D. (2016). Insect-induced plant phenotypes: revealing mechanisms through comparative genomics of galling insects and their hosts. Am. J. Bot. 103, 979-981. doi: 10.3732/ajb.1600111

Nyman, T., and Julkunen-Tiitto, R. (2000). Manipulation of the phenolic chemistry of willows by gall-inducing sawflies. Proc. Natl. Acad. Sci. U.S.A. 97, 13184-13187. doi: 10.1073/pnas.230294097

Ogah, E. O., Smart, L. E., Woodcock, C. M., Caulfield, J. C., Birkett, M. A., Pickett, J. A., et al. (2017). Electrophysiological and behavioral responses of female African rice gall midge, Orseolia oryzivora Harrish and Gagné, to host plant volatiles. J. Chem. Ecol. 43, 13-16. doi: 10.1007/s10886-016-0788-6

Papanastasiou, S. A., Bali, E. M. D., Ioannou, C. S., Papachristos, D. P., Zarpas, K. D., and Papadopoulos, N. T. (2017). Toxic and hormetic-like effects of three components of citrus essential oils on adult Mediterranean fruit flies (Ceratitis capitata). PLoS One 12:e0177837. doi: 10.1371/journal.pone. 0177837

Proffit, M., Schatz, B., Borges, R. M., and Hossaert-McKey, M. (2007). Chemical mediation and niche partitioning in non-pollinating fig-wasp communities. J. Anim. Ecol. 76, 296-303. doi: 10.1111/j.1365-2656.2007.01213.x

Raman, A. (2011). Morphogenesis of insect-induced plant galls: facts and questions. Flora Morphol. Distrib. Funct. Ecol. Plants 206, 517-533. doi: 10.1016/j.flora.2010.08.004

Rand, K., Bar, E., Ari, M. B., Davidovich-Rikanati, R., Dudareva, N., Inbar, M., et al. (2017). Differences in monoterpene biosynthesis and accumulation in Pistacia palaestina leaves and aphid-induced galls. J. Chem. Ecol. 43, 143-152. doi: 10.1007/s10886-016-0817-5

Rand, K., Bar, E., Ben-Ari, M., Lewinsohn, E., and Inbar, M. (2014). The monoand sesquiterpene content of aphid-induced galls on Pistacia palaestina is not a simple reflection of their composition in intact leaves. J. Chem. Ecol. 40, 632-642. doi: 10.1007/s10886-014-0462-9

Ranganathan, Y., and Borges, R. M. (2009). Predatory and trophobiont-tending ants respond differently to fig and fig wasp volatiles. Anim. Behav. 77, 1539-1545. doi: 10.1016/j.anbehav.2009.03.010

Ranganathan, Y., Ghara, M., and Borges, R. M. (2010). Temporal associations in fig-wasp-ant interactions: diel and phenological patterns. Entomol. Exp. Appl. 137, 50-61. doi: 10.1111/j.1570-7458.2010.01038.x

Rasmann, S., Ali, J. G., Helder, J., and van der Putten, W. H. (2012). Ecology and evolution of soil nematode chemotaxis. J. Chem. Ecol. 38, 615-628. doi: $10.1007 / \mathrm{s} 10886-012-0118-6$ 
Rasmann, S., Bennett, A., Biere, A., Karley, A., and Guerrieri, E. (2017). Root symbionts: powerful drivers of plant above- and belowground indirect defences. Insect Sci. 24, 947-960. doi: 10.1111/1744-7917. 12464

Rhodes, B. C., Blair, C. P., Takahashi, M. K., and Abrahamson, W. G. (2012). The role of olfactory cues in the sequential radiation of a gall-boring beetle, Mordellistena convicta. Ecol. Entomol. 37, 500-507. doi: 10.1111/j.1365-2311. 2012.01391.x

Rostás, M., Maag, D., Ikegami, M., and Inbar, M. (2013). Gall volatiles defend aphids against a browsing mammal. BMC Evol. Biol. 13:193. doi: 10.1186/14712148-13-193

Santos, S. A., Mota, L., Malheiro, R., Silva, F., Campos, M., de Pinho, P. G., et al. (2016). Changes in volatile compounds of Dittrichia viscosa caused by the attack of the gall-forming dipteran Myopites stylatus. Ind. Crop Prod. 87, 71-77. doi: 10.1016/j.indcrop.2016.04.002

Segar, S. T., Pereira, R. A., Compton, S. G., and Cook, J. M. (2013). Convergent structure of multitrophic communities over three continents. Ecol. Lett. 16, 1436-1445. doi: 10.1111/ele.12183

Silvia, M. S., and Connor, E. F. (2017). Differences in meristems between monocots and dicots and susceptibility to attack by gall-inducing insects. Arthropod Plant Interac. 11, 485-494. doi: 10.1007/s11829-017-9502-z

Simon, J. C., Biere, A., and Sugio, A. (2017). The promises and challenges of research on plant-insect-microbe interactions. Insect Sci. 24, 904-909. doi: 10.1111/1744-7917.12536

Souza, C. D., Pereira, R. A., Marinho, C. R., Kjellberg, F., and Teixeira, S. P. (2015). Diversity of fig glands is associated with nursery mutualism in fig trees. Am. J. Bot. 102, 1564-1577. doi: 10.3732/ajb.1500279

Stone, G. N., and Cook, J. M. (1998). The structure of cynipid oak galls: patterns in the evolution of an extended phenotype. Proc. R. Soc. Lond. B 265, 979-988. doi: 10.1098/rspb.1998.0387

Takei, M., Yoshida, S., Kawai, T., Hasegawa, M., and Suzuki, Y. (2015). Adaptive significance of gall formation for a gall-inducing aphids on Japanese elm trees. J. Insect Physiol. 72, 43-51. doi: 10.1016/j.jinsphys.2014.11.006

Tooker, J. F., Crumrin, A. L., and Hanks, L. M. (2005). Plant volatiles are behavioral cues for adult females of the gall wasp Antistrophus rufus. Chemoecology 15, 85-88. doi: 10.1007/s00049-005-0298-4

Tooker, J. F., and De Moraes, C. M. (2008). Gall insects and indirect plant defenses: a case of active manipulation? Plant Signal. Behav. 3, 503-504. doi: 10.4161/psb. 3.7.6184

Tooker, J. F., and Hanks, L. M. (2004). Stereochemistry of host plant monoterpenes as mate location cues for the gall wasp Antistrophus rufus. J. Chem. Ecol. 30, 473-477. doi: 10.1023/B:JOEC.0000017995.83676.c9

Tooker, J. F., and Helms, A. M. (2014). Phytohormone dynamics associated with gall insects, and their potential role in the evolution of the gall-inducing habit. J. Chem. Ecol. 40, 742-753. doi: 10.1007/s10886-014-0457-6

Tooker, J. F., Koenig, W. A., and Hanks, L. M. (2002). Altered host plant volatiles are proxies for sex pheromones in the gall wasp Antistrophus rufus. Proc. Natl. Acad. Sci. U.S.A. 99, 15486-15491. doi: 10.1073/pnas.252626799
Tooker, J. F., Rohr, J. R., Abrahamson, W. G., and De Moraes, C. M. (2008). Gall insects can avoid and alter indirect plant defenses. New Phytol. 178, 657-671. doi: 10.1111/j.1469-8137.2008.02392.x

Turlings, T. C., and Erb, M. (2018). Tritrophic interactions mediated by herbivoreinduced plant volatiles: mechanisms, ecological relevance, and application potential. Annu. Rev. Entomol. 63, 433-452. doi: 10.1146/annurev-ento020117-043507

Uesugi, A., Morrell, K., Poelman, E. H., Raaijmakers, C. E., and Kessler, A. (2016). Modification of plant-induced responses by an insect ecosystem engineer influences the colonization behaviour of subsequent shelter-users. J. Ecol. 104, 1096-1105. doi: 10.1111/1365-2745.12587

Uesugi, A., Poelman, E. H., and Kessler, A. (2013). A test of genotypic variation in specificity of herbivore-induced responses in Solidago altissima L. (Asteraceae). Oecologia 173, 1387-1396. doi: 10.1007/s00442-013-2717-5

Wang, J., Chung, S. H., Peiffer, M., Rosa, C., Hoover, K., Zeng, R., et al. (2016). Herbivore oral secreted bacteria trigger distinct defense responses in preferred and non-preferred host plants. J. Chem. Ecol. 42, 463-474. doi: 10.1007/s10886016-0712-0

Webster, B., and Cardé, R. T. (2017). Use of habitat odour by host-seeking insects. Biol. Rev. 92, 1241-1249. doi: 10.1111/brv.12281

Wool, D., and Burstein, M. (1991). A galling aphid with extra life-cycle complexity: population ecology and evolutionary considerations. Res. Popul. Ecol. 33, 307-322. doi: 10.1007/BF02513556

$\mathrm{Xu}, \mathrm{H}$., and Turlings, T. C. (2018). Plant volatiles as mate-finding cues for insects. Trends Plant Sci. 23, 100-111. doi: 10.1016/j.tplants.2017. 11.004

Yadav, P., and Borges, R. M. (2017). The insect ovipositor as a volatile sensor within a closed microcosm. J. Exp. Biol. 220, 1554-1557. doi: 10.1242/jeb. 152777

Yadav, P., Desireddy, S., Kasinathan, S., Bessière, J.-M., and Borges, R. M. (2018). History matters: oviposition resource acceptance in an exploiter of a nursery pollination mutualism. J. Chem. Ecol. 44, 18-28. doi: 10.1007/s10886-0170914-0

Zhao, C., Escalante, L. N., Chen, H., Benatti, T. R., Qu, J., Chellapilla, S., et al. (2015). A massive expansion of effector genes underlies gall-formation in the wheat pest Mayetiola destructor. Curr. Biol. 25, 613-620. doi: 10.1016/j.cub. 2014.12.057

Conflict of Interest Statement: The author declares that the research was conducted in the absence of any commercial or financial relationships that could be construed as a potential conflict of interest.

Copyright (c) 2018 Borges. This is an open-access article distributed under the terms of the Creative Commons Attribution License (CC BY). The use, distribution or reproduction in other forums is permitted, provided the original author(s) and the copyright owner(s) are credited and that the original publication in this journal is cited, in accordance with accepted academic practice. No use, distribution or reproduction is permitted which does not comply with these terms. 